\title{
Щодо формування шкал оцінювання рівня (стану) воєнно- економічної безпеки держави
}

\author{
Ігор Москаленко * А \\ А Національний університет оборони України імені Івана Черняховського, проспект Повітрофлотський, 28, м. Київ, 03049, Україна
}

Received: October 04, 2020 | Revised: October 25, 2020 | Accepted: October 31, 2020

JEL Classification: B23, B41, C20.

DOI: $10.33445 /$ sds.2020.10.5.6

\begin{abstract}
Анотація
В будь-якій країні обсяг оборонних витрат залежить від рівня воєнної та економічної безпеки держави. Тобто, щоб адекватно відреагувати на зміни стану воєнно-економічної безпеки країни необхідно оцінити їі рівень з урахуванням ресурсних можливостей держави на час оцінювання, та тільки після цього приймати рішення щодо частки збільшення, або зменшення оборонних витрат країни. Побудова шкали оцінювання рівня воєнноекономічної безпеки, яка дозволяє дослідити чутливість отриманої оцінки рівня воєнноекономічної безпеки держави до зміни вхідних даних та підвищити стабільність прийнятих рішень за цією оцінкою є актуальним та необхідним завданням сьогодення. В статті шкалу оцінювання рівня воєнно-економічної безпеки пропонується задавати на основі нечіткомножинної математичної моделі. Використання нечітко-множинної математичної моделі для побудови шкали оцінювання рівня воєнно-економічної безпеки, надасть можливість оперувати частковими нечіткими показниками оцінок за складовими показників ресурсного забезпечення воєнно-економічної безпеки держави з метою можливості дослідження питань аналізу чутливості отриманої оцінки рівня воєнно-економічної безпеки держави до зміни вхідних даних та підвищення стабільності прийнятих рішень відповідно до цієї оцінки.
\end{abstract}

Ключові слова: воєнна безпека, економічна безпека, воєнно-економічна безпека, оборонні компоненти, нечітко-множинна математична модель, інтегральна функція, ресурсні можливості, шкала оцінювання.

\section{Постановка проблеми}

Втручання Російської Федерації у внутрішні справи України викликало підвищення рівня зовнішніх та внутрішніх небезпек для України та всього світу. Сьогодні, слова колишнього Генерального секретаря НАТО, «свобода не приходить безкоштовно, і будь-яке рішення, прийняте для того, щоб покращити нашу економіку, не повинно зіштовхнути нас у кризу іншого роду - кризу безпеки", чітко підкреслюють помилки щодо економії на власній безпеці [1-4, 9]. Крім того, за думкою лідерів провідних країн Європи, дії Росії підривають євроатлантичну безпеку та створюють передумови напруженості та недовіри у відносинах між державами. Більшість провідних країн світу дотримуються тенденцій колективного захисту, але й не відкидають питання ефективного розвитку власних збройних сил. Яскравим свідченням цього $€$ збільшення оборонних витрат цих країн на 10-60\% після 2014 року $[1-3,9]$.

Розміри зростання оборонних витрат країн залежать від показників рівня воєнної та економічної безпеки держави на час їх визначення. Тобто, щоб адекватно відреагувати на зміни стану воєнноекономічної безпеки країни необхідно оцінити ії рівень з урахуванням ресурсних

\footnotetext{
* Corresponding author: здобувач, e-mail: kidmos@bigmir.net, ORCID: 0000-0002-7822-6419
} 
можливостей держави на час оцінювання, та тільки після цього приймати рішення щодо частки збільшення, або зменшення оборонних витрат країни $[6,7,9]$.

Таку оцінку можна здійснювати відповідно до визначених в $[5,8]$ методичних підходів. Але, одним з недосконалих місць такого оцінювання $\epsilon$ формування шкал оцінювання рівня (стану) забезпеченості ресурсами держави та рівня воєнно-економічної безпеки взагалі за детермінованим принципом. Побудова їх за цим принципом робить оцінки не достатньо чутливими до змін або помилок вхідних параметрів оцінювання, і не дає можливості оцінити стабільність прийнятого рішення за розрахованими оцінками. Тому питання пошуку спроб удосконалення процесу побудови шкал оцінювання в існуючому методичному підході оцінювання рівня воєнно-економічної безпеки держави й визначає актуальність цієї статті.

\section{Аналіз останніх досліджень та публікацій}

Аналіз останніх досліджень і публікацій присвячених питанням оцінювання рівнів воєнної та економічної безпеки [1-9], свідчать про наявність у фахівців та науковців своїх поглядів щодо вирішення цих питань. Існуючи підходи мають сенс, але й вони мають свої недосконалості. Одним з таких недоліків визначених в $[5,8]$ підходів $\epsilon$ формування шкали оцінювання рівня воєнноекономічної безпеки за детермінованим принципом, що не дозволяє оцінити чутливість отриманих оцінок до змін вхідних параметрів оцінювання та визначити ступінь стабільності прийнятих рішень на основі цих оцінок.

\section{Постановка завдання}

Зважаючи на зазначене, метою статті $\epsilon$ визначення одного з підходів до формування (побудови) шкал оцінювання рівня (стану) воєнно-економічної безпеки держави, який дозволить визначати чутливість отриманої оцінки рівня воєнно-економічної безпеки держави до зміни вхідних параметрів оцінювання та підвищити стабільність прийнятих рішень.

\section{Виклад основного матеріалу}

Процес оцінювання рівня воєнноекономічної безпеки держави передбачає формування поглядів керівників держави щодо достатності його відносно необхідного рівня за різних умов змін обстановки навколо країни на момент або період оцінювання. Необхідний рівень воєнно-економічної безпеки визначається відносно прогнозних загроз для країни на визначений момент або період, які формують відповідний стан 3 С та інших військових формувань, що будуть залучатися для забезпечення прогнозованого рівня воєнної безпеки. Для забезпечення визначеного стану 3 С та інших військових формувань, державі потрібно мати відповідні можливості щодо формування цього стану. Одними із головних можливостей є ресурсні можливості держави (фінансові, матеріальні та людські). Стан воєнно-економічної безпеки держави залежить від загальних інтегральних показників, які описують відповідно стан кожної з ресурсних можливостей держави на час (період) оцінювання $[5,8,9]$. Ці складові взаємопов'язані між собою та кожна з них впливає на загальний стан (рівень) воєнноекономічної безпеки в державі взагалі.

3 метою розуміння, в якому стані перебуває чи буде перебуватиме показник рівня воєнно-економічної безпеки держави, необхідно періодично проводити його оцінювання 3 метою обґрунтованого, коректного корегування процесів розвитку силових структур країни. Для цього був запропонований у $[5,8]$ методичний апарат оцінювання рівня воєнної безпеки держави за показниками забезпеченості держави 
різними видами ресурсів. Сьогодні стан воєнно-економічної безпеки держави оцінюється шляхом інтуїтивних рішень [1].

Рівень воєнно-економічної безпеки держави безпосередньо залежить від показників забезпеченості держави за складовими відповідних ресурсних можливостей, які також можуть складатися із часткових показників. Тобто розрахунок загального показника рівня воєнноекономічної безпеки за ресурсними можливостями $(W)$ потребує інтегрування значної кількості показників в єдиний показник.

$$
\left\{\begin{array}{l}
W=f\left(E_{i}\right), \\
E_{i}=f\left(w_{j}, w_{l}, w_{k}\right), \\
w_{j}, w_{l}, w_{k}=f\left(B_{b}, \ldots, V_{p}\right) .
\end{array}\right.
$$

де $E_{i}$ - показник рівня забезпеченості за $i$ ми ресурсними можливостями; $w_{j}, . w_{l}, w_{k}$ - показники забезпеченості за складовими відповідних ресурсних можливостей протягом періоду або на час оцінювання; $B_{b}, \ldots, V_{p}$ - показники забезпеченості за складовими рівня нижче на ступінь.

Більшість визначених показників повинні задаватися, тобто бути нормативними (наприклад, необхідний чи можливий показник забезпеченості (або наявності) ресурсних можливостей держави). Але для особи, яка приймає рішення щодо формування (уточнення) загального показника рівня воєнно-економічної безпеки держави, треба знати не просто кількісні оцінки показників кожної 3 ресурсних можливостей, а і те, в якому ступені вони визначають загальний показник рівня воєнно-економічної безпеки на визначений час (період) оцінювання в цілому.

Відповідальність за прийняте рішення завжди лежить на тому, хто це рішення приймає, тому й аналіз особистих рішень на визначення та подальше уточнення майбутніх

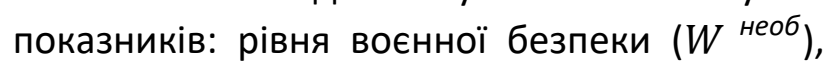
рівнів забезпеченості ресурсними можливостями $\left(E_{i}^{\text {необ}}\right)$ та рівнів забезпеченості за складовими ресурсних можливостей $\left(w_{j}^{\text {факт }}, w_{l}^{\text {факт }}, w_{k}^{\text {факт }}\right)$, ця особа повинна проводити особисто. Це завдання ускладнюється тим, що часткових показників, які впливають на показники рівня забезпеченості ресурсними можливостями та самих ресурсних можливостей декілька, тобто вимагається якимось чином згорнути їх в один загальний показник оцінки, який потім порівнюється із визначеним на час (період) оцінювання.

Але неможливість мати однорідну та презентабельну статистику як для окремих показників рівнів ресурсних можливостей, так і для загального показника рівня воєнноекономічної безпеки в цілому, робить сумнівним використання для оцінювання їх стану детермінованих, ймовірнісних математичних моделей. Однозначність прийняття рішення щодо досягнення необхідного показника рівня воєнноекономічної безпеки чи забезпеченості за ресурсними можливостями держави та їх складовими потребує більш глибокого та детальнішого дослідження. А чим більше та детальніше проводиться дослідження процесу оцінювання зазначених показників, та в силу відсутності інформації щодо практичних значень цих показників та за різних номіналів вимірювання рівня їх досягнення, виникають невизначеності в оцінці, та деякі з них взагалі опиняються недоступними для вимірювання (наприклад, оцінка рівня воєнно-економічної безпеки взагалі). Тобто самі рівні забезпеченості (наявності) як ресурсними можливостями так і рівень воєнно-економічної безпеки держави на час (період) можуть оцінюватися за допомогою логічних висновків. Наприклад, шкала рівня забезпеченості за ресурсною можливістю може виглядати так: $E_{1}-$ найгірший рівень; $E_{2}-$ недостатній рівень; $E_{3}$ - середній рівень; $E_{4}-$ достатній рівень; $E_{5}-$ найкращий рівень (рис. 1). 


$$
\mu\left(X_{\Sigma}\right)
$$

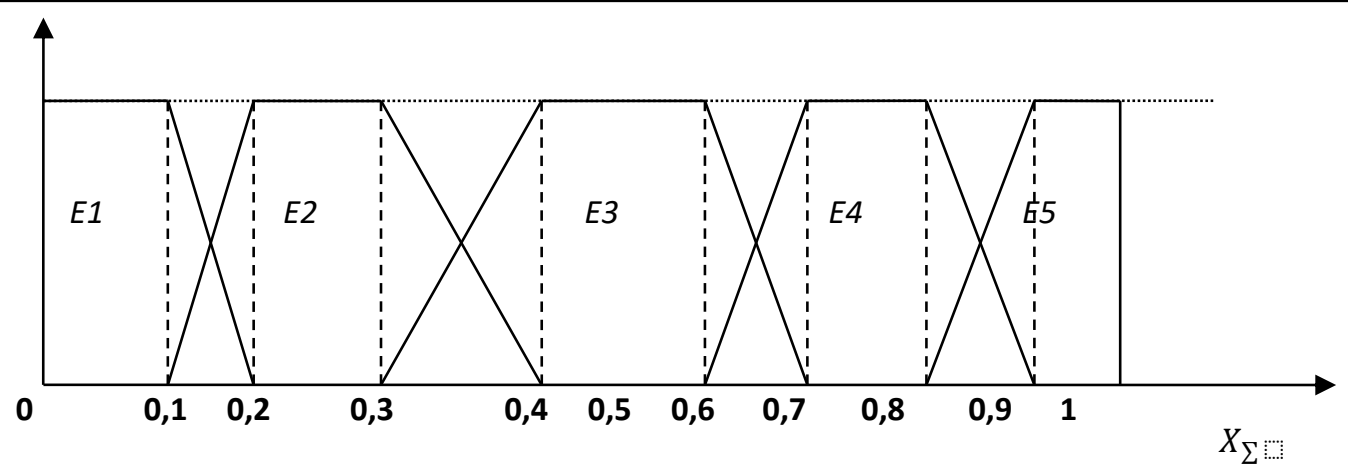

Малюнок 1 - Узагальнений показник рівня забезпеченості будь-яким видом ресурсу

Кожен із показників визначеної шкали оцінювання передбачає деяку завчасно розраховану частину від загального показника, що оцінюється. Також деякі показники складових ресурсних можливостей теж будуть визначатися на основі логічних висновків, що спонукає до наявності неоднозначності оцінювання за різних умов вхідних даних. Виникає ситуація, коли не можливо чітко відповісти, що за такого розрахованого показника рівень забезпеченості ресурсними можливостями або рівень воєнно-економічної безпеки країни на цей час належить чітко тій чи іншій оцінці. Але рішення за отриманою оцінкою повинно бути однозначним, бо оцінка може носити двобічний характер, тобто необхідно оцінити ступінь приналежності її до визначеної області шкали з подальшим розрахунком загального показника для прийняття рішень за обраним математичним підходом. Далі оцінюються чутливість отриманої оцінки до змін вхідних даних та стабільності прийнятого рішення за отриманою оцінкою.

Тому, враховуючи чинники оцінювання та особливості їі проведення за основу оцінки рівня воєнно-економічної безпеки держави на основі оцінок ресурсних можливостей, пропонується використовувати нечіткомножинну математичну модель, яка дозволить оперувати частковими нечіткими показниками оцінок за складовими ресурсного забезпечення воєнноекономічної безпеки держави. Загальний повний нечіткий показник “Рівень воєнно- економічної безпеки держави" позначимо $(W)$ показники рівня забезпеченості за ресурсними можливостями позначимо $\mathrm{E}_{i}, i=$ $\overline{1, M} . \mathrm{E}_{i}$ розіб'ємо на п'ять нечітких підмножин $\mathrm{E}_{i}, g=\overline{1,5}$ (рис. 2), кожна з яких задається своєю функцією приналежності $\mu_{g}\left(X_{\Sigma}\right), g=\overline{1,5}, \quad$ де $X_{\Sigma} \in[0,1]$ узагальнений показник [10-12].

Загальний показник рівня воєнної безпеки як і показник рівня забезпеченості ресурсними можливостями на основі використання нечітких оцінок його стану можна представити як [10]: $W_{\mathrm{i}}^{1}-$ дуже низький; $W_{\mathrm{i}}^{2}$ - низький; $W_{\mathrm{i}}^{3}$ - середній; $W_{\mathrm{i}}^{4}-$ високий; $W_{\mathrm{i}}^{5}-$ дуже високий (рис. 5). Тобто як i в попередньому випадку узагальнений показник розбито на п'ять нечітких підмножин $W, g=\overline{1,5}$ (рис. 2), кожна 3 яких задається своєю функцією приналежності $\mu_{g}\left(X_{\Sigma}\right), g=\overline{1,5}, X_{\Sigma} \in$ $[0,1]$.

Як і зазначалося для цього показника формується аналогічна шкала, в якій також кожен із показників займає відповідну частину (підмножину) від загального показника (рис. 2). Задані проміжки, на які розбивається шкала кожного із показників, що оцінюються, визначаються аналогічним способом нечітко-множинної логіки за допомогою нечітких чисел (рис. 3), які можуть формуватися на основі узагальненої функції Харінгтона [12], або експертного опитування як із врахуванням компетентності експертів так і без нього [10]. 

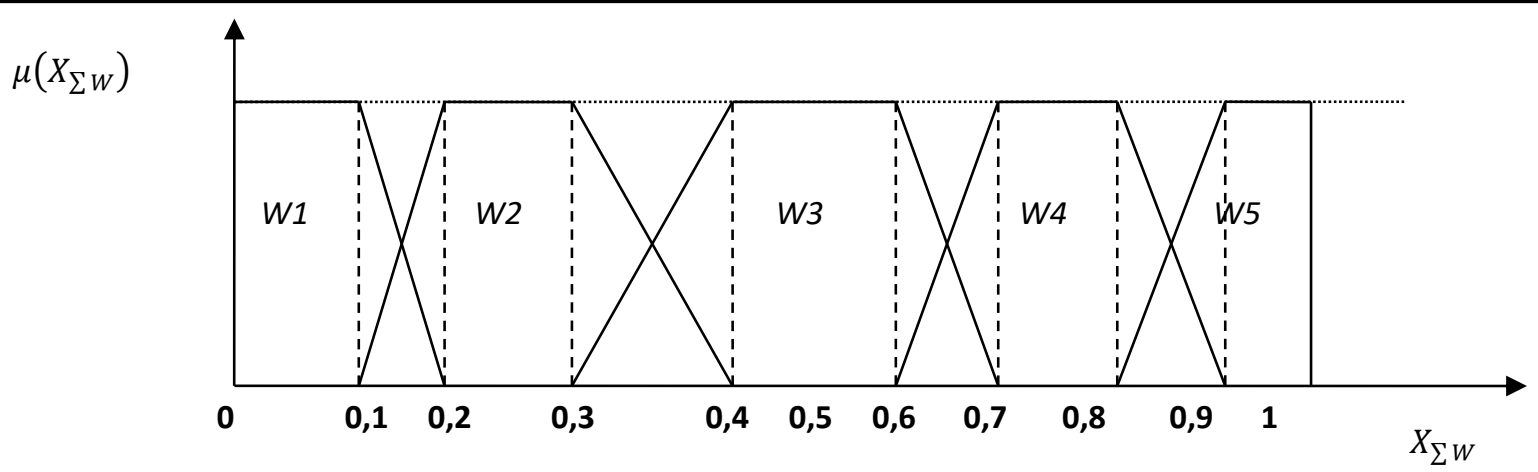

Малюнок 2 - Узагальнений показник “Рівень воєнно-економічної безпеки”

Межі носіїв (рис. 3) $\left(n_{g}\right.$ ) (якщо $x \in n$, то $\mu(x)>0)$ і ядро $\left(r_{g}\right)$ (якщо $x \in r$ то $\mu(x)=1$ ) нечітких чисел задані аналогічно узагальненій функції Харрінгтона, але пропонується їх задавати на основі експертного опитування [5, 8]. Використання трапецеїдальних функцій приналежності, як показано в [12], не знижує загальності результатів, але значно спрощує роботу системи підтримки прийняття рішень. В цьому випадку, будь-яке нечітке число (нечітка підмножина) задається чотирма числами $(a, b, c, d)$, де $[a, d]=n-$ носій нечіткого числа; $[b, c]=r$ - ліва та права бокові гілки функції приналежності, які описуються рівняннями (рис. 3)

$$
\mu(x)=\frac{x-a}{b-a}, \mu(x)=\frac{d-x}{d-c} .
$$

Узагальнені показники $X_{\Sigma}$ складової будь-якої ресурсної можливості, також оцінюються за шкалою своїх часткових показників та далі інтегруються в узагальнений показник відповідної до ресурсної можливості. В подальшому здійснюється оцінка його стану за відповідною завчасно визначеною шкалою типу рис. 1. Для отримання кінцевого результату щодо рівня воєнно-економічної безпеки отримані показники рівня забезпеченості за ресурсними можливостям інтегруються в загальний показник рівня воєнно-економічної безпеки 3 урахуванням показників їх вкладу в загальний показник. Оцінювання проводиться за завчасно визначеною шкалою (рис. 2).

Для задавання відповідних функцій приналежності для кожного із показників, що будуть оцінюватися, пропонується використовувати процедуру експертного опитування. Якщо на питання щодо приналежності будь-якого значення узагальненого показника відповідній його частині $\left(x_{\kappa} \in \Pi\left(X_{\Sigma}\right)\right) N_{1}$ експертів $3 N$ відповідає позитивно, то відповідно за формулою (3) формується функція приналежності:

$$
\mu\left(X_{\Sigma}\right)=\frac{N_{1}}{N} .
$$

За такої побудови вона прийме вигляд як на рис. 3. Під час формування усієї шкали початок носія кожного наступного показника описаного нечітким число починається з кінця ядра попереднього. В деяких випадках, вплив кожного часткового показника на узагальнений показник оцінювання $X_{\Sigma}$ різний, тому виникає необхідність кількісного визначення коефіцієнтів пріоритетності 3 метою формування адекватних проміжків, на які розбивається узагальнений показник. У випадку, коли показники можуть бути тільки проранжовані за зменшенням їх значимості, то для визначення коефіцієнтів пріоритетності може бути використана шкала Фішберна $[11,12]$.

Для прийняття рішень на основі отриманої оцінки за кожним узагальненим показником щодо визначення його рівня у разі не потрапляння отриманої оцінки до ядра нечіткого числа, що описує відповідний інтервал узагальненого показника, визначаються оцінки для обох часткових показників із визначенням величини приналежності $\left(\mu_{\kappa}^{1}, \mu_{\kappa}^{2}\right)$ ії до кожного інтервалу $\left(\Pi_{1}, \Pi_{2}\right)$ (рис. 3, рис. 4). Далі 
визначається ступінь приналежності $\left(\lambda_{\kappa}^{1}, \lambda_{k}^{2}\right)$ оцінки до кожного із них:

$$
\lambda \underset{\kappa}{1}=\frac{\text { площина } x_{k} \cap \Pi_{1}}{\text { площина } x_{k} \cap \Pi_{2}} .
$$

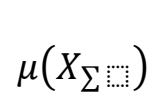

де: $U$ i $\cap$ означають операції перетинання та об'єднання нечітких чисел із отриманою оцінкою.

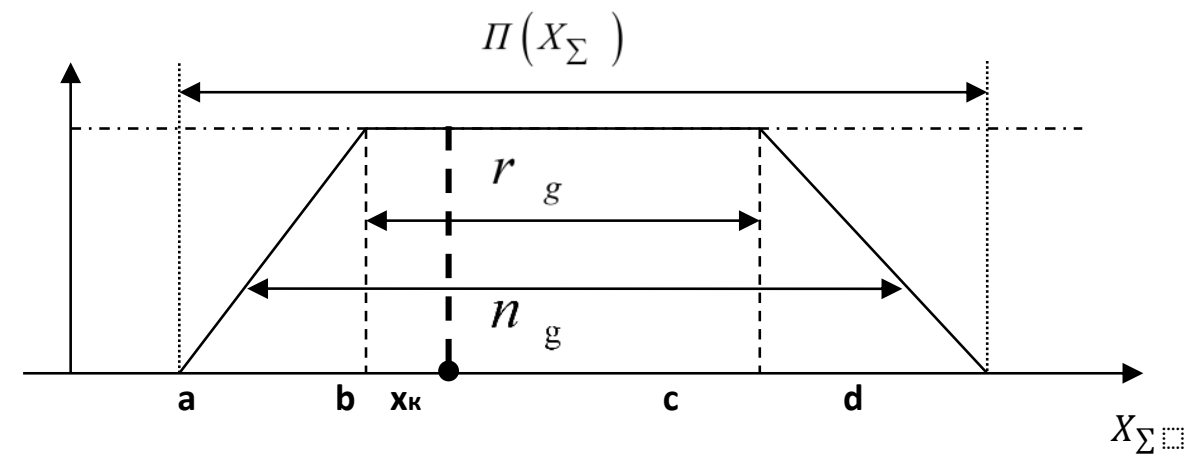

Малюнок 3 Відображення нечіткого числа

\begin{abstract}
Для трапецеїдальних функцій приналежності обчислювання ступеня приналежності $\left(\lambda_{\kappa}\right)$ розрахованої оцінки до визначеного інтервалу (відповідного рівня) у відповідності з (4) не викликає ускладнень. Наприклад, відповідно до рис. 4 розрахунок ступеня приналежності до відповідного показника рівня здійснюється так
\end{abstract}

$$
\lambda_{1}=\frac{S_{x_{1} B x_{K}}}{S_{x_{1} B C X_{2}}} ; \lambda_{2}=\frac{S_{x_{K} A x_{2}}}{S_{x_{1} B C X_{2}}+S_{A B C}} .
$$

Якщо $\lambda_{1}>\lambda_{2}$, то перевага віддається першому показнику. Для чітких оцінок, коли $x_{\kappa} \in r_{g}$ із інтервалу $\Pi\left(X_{\Sigma}\right)$ узагальненого показника, тоді й:

$$
\lambda=\mu\left(x_{k}\right)=1 .
$$

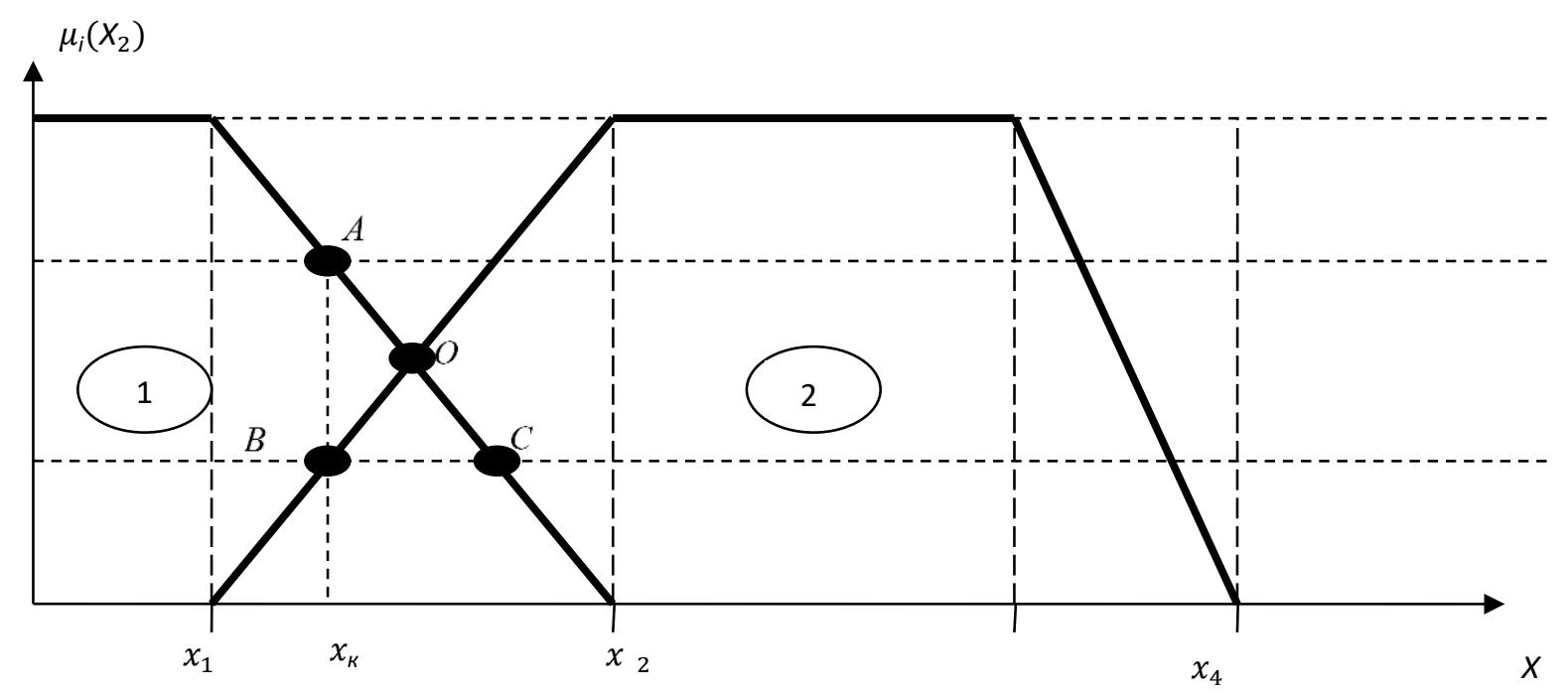

Малюнок 4 - Відображення розрахунку ступеня приналежності $\lambda_{1}, \lambda_{2}$

Якщо $\lambda_{1}>\lambda_{2}$, то перевага віддається першому показнику. Для чітких оцінок, коли $x_{\kappa} \in r_{g}$ із інтервалу $\Pi\left(X_{\Sigma}\right)$ узагальненого показника, тоді й:

$$
\lambda=\mu \quad\left(x_{\kappa}\right)=1 .
$$

Після розрахунку часткових показників відбувається поступове їх інтегрування в загальні показники шляхом згортання за допомогою відносних показників із врахуванням величини вкладу кожного часткового показника в загальний на ступінь вище, наприклад:

$$
\begin{gathered}
W=\sum_{i=1}^{M} \alpha_{i} \cdot \frac{E_{\mathrm{i}}^{\text {факт }}}{\mathrm{E}_{\mathrm{i}}^{\text {необ }}} \quad \text { чи } E_{\mathrm{i}}^{\text {факт }}= \\
\sum_{j}^{R} \alpha_{j} \cdot \frac{w_{j}^{\text {факт }}}{w_{j}^{\text {необ }},}
\end{gathered}
$$




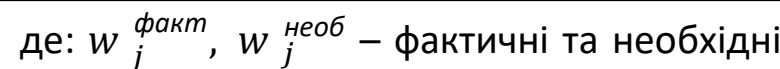
показники забезпеченості за складовими ресурсних можливостей на час оцінювання; $\alpha_{i}, \alpha_{j}-$ коефіцієнти величини вкладу кожного часткового показника в загальний (згорнутий чи інтегрований) показник.

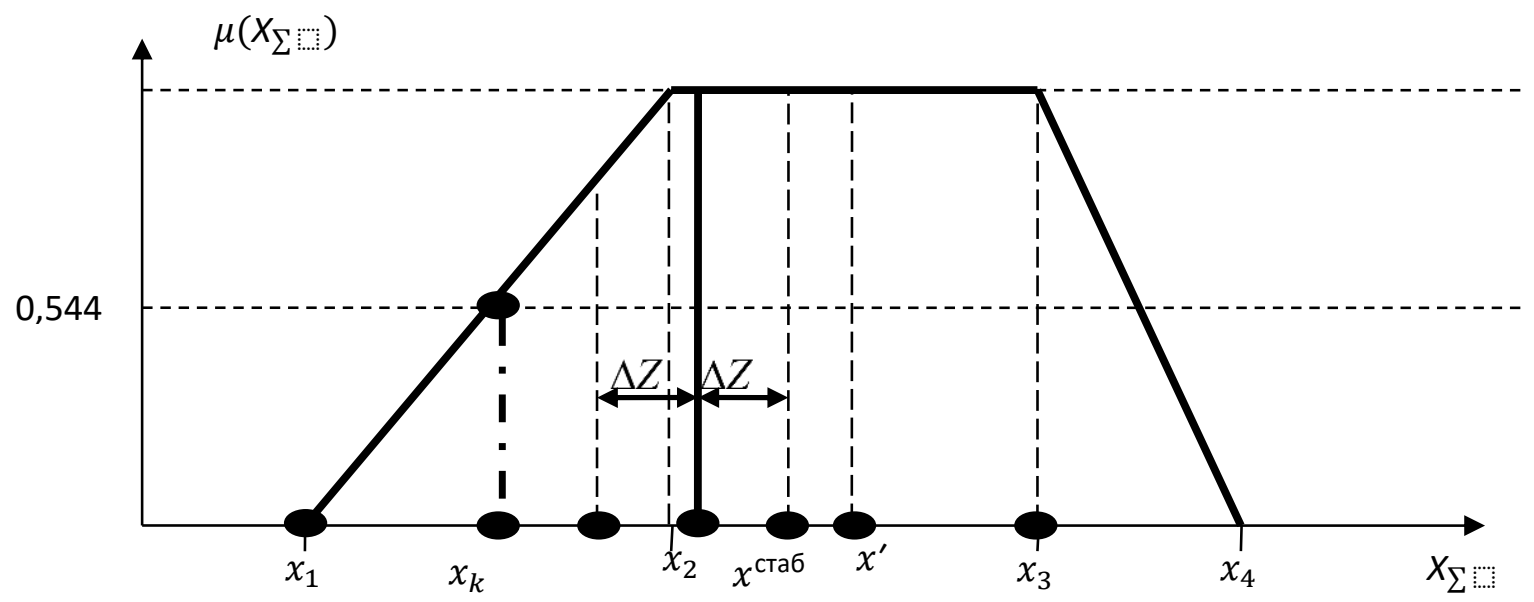

Рисунок 5 - Відображення розрахунку чутливості та стабільності отриманих результатів оцінювання

Коефіцієнт величини вкладу, кожного часткового показника в загальний показник визначається на основі методу експертного опитування.

Тому як шкалу оцінювання рівня воєнноекономічної безпеки пропонується задавати на основі нечітко-множинної математичної моделі виникає необхідність оцінювання стійкості та стабільності отриманих результатів оцінювання за кожним із інтегральних показників. Таке оцінювання надасть інформацію щодо чутливості результатів отриманих оцінок до змін вхідних параметрів на момент оцінювання та охарактеризує стабільність прийнятих рішень на основі отриманих результатів оцінювання.

У загальному випадку, аналіз отриманих результатів оцінювання щодо стабільності отриманих результатів до незначних змін вхідних параметрів можна провести на основі нечіткого співвідношення переваги (нечіткої функції від чіткого чи нечіткого аргументу) узагальненого показника $x_{\Sigma}$, який також може задаватися нечітким числом. Здійснюється така математична операція на основі аналізу показника нечіткого співвідношення переваги (нечіткої функції від чіткого чи нечіткого аргументу) узагальненого показника $x_{\Sigma}$, яке $\epsilon$ нечітким числом.
Порядок розрахунку стабільності отриманої оцінки відносно заданого нечіткого числа із відповідною функцією приналежності можна представити як на рис. 5:

По-перше розраховується центральна оцінка відносно якої здійснюється розрахунок $x^{\prime}$ :

$$
x^{\prime}=\frac{x_{4}-x_{1}}{2}+x_{1}
$$

По-друге розраховується значення можливого стабільного відхилення $\Delta Z$ від визначеної завчасно стабільної точки розташування отриманої оцінки $x^{\text {стаб }}$ (аргументу):

$$
\Delta Z=\Delta E^{\text {необ}}\left(W^{\text {необ}}\right)=\frac{x^{\prime}-x_{1}}{4} .
$$

Наведемо приклад практичного розрахунку. Відповідно до запропонованого прикладу за умови отримання результату оцінювання на рівні $x_{k}=0,64$. Вихідні дані до розрахунку обираються відповідно до рис. 5 .

Якщо $x_{1}=0,6 ; x_{2}=0,7 ; x_{3}=0,9 ; x_{4}=1$; $x_{k}=0,64$, тоді: $x^{\prime}=\frac{1-0,6}{2}+0,6=0,8$

$$
\begin{aligned}
\Delta Z=\Delta E^{\text {необ}}( & \left.W^{\text {необ }}\right)=\frac{0,8-0,6}{4} \\
& =0,05 \Delta x^{\text {стаб }} \\
& =\left(\frac{0,8-0,6}{2}+0,6\right) \pm 0,05 ;
\end{aligned}
$$

$\Delta x^{\text {cmaб }}=[0,65 ; 0,75]$;

$x_{k} \notin \Delta x^{\text {стаб }} \notin[0,65 ; 0,75]$. 
у цьому випадку, отримана оцінка не стабільна та чутлива до змін вхідних даних, тому й рішення на основі цієї оцінки повинно передбачати можливі ризики щодо недосягнення запланованого необхідного результату. Особа, яка буде приймати рішення повинна уточнити можливі похибки прогнозованого необхідного результату та мати можливості скорегувати майбутній результат.

\section{Висновки}

Таким чином, в статті надана пропозиція щодо удосконалення шкали оцінювання рівня воєнно-економічної безпеки, запропонованому в [5, 8] методичному апараті. Це удосконалення передбачає використання нечітко-множинної математичної моделі для побудови шкали оцінювання рівня воєнно-економічної безпеки, що надасть можливість оперувати частковими нечіткими показниками оцінок за складовими показників ресурсного забезпечення воєнно-економічної безпеки держави з метою можливості дослідження питань аналізу чутливості отриманої оцінки рівня воєнно-економічної безпеки держави до зміни вхідних даних та підвищення стабільності прийнятих рішень відповідно до цієї оцінки.

\section{Список використаних джерел}

1. Указ Президента України №555/2015 Про рішення Ради національної безпеки і оборони України від 2 вересня 2015 року "Про нову редакцію Воєнної доктрини України" URL: www.president.gov.ua/ documents/5552015-19443.

2. Пріоритети розвитку Збройних Сил України 3 урахуванням участі у гібридній війні 2015-2016 / URL: http//www. president.gov.ua/documents.

3. Обґрунтування перспективи економічного розвитку України у 2015-2016 pp. URL: econa.org.ua/index.php/econ

4. Про основи національної безпеки України / Закон України (Відомості Верховної Ради України (ВВР), 2003, N 39, ст.351).

5. Семененко, О. М., Науменко М. П. Методика оцінювання стану економічної складової воєнної безпеки України. $3 б$. наук. пр. ЦНДІ ЗС України. Київ, 2012. № 4 (62). С. $39-49$.

6. Мунтіян В.І. Економічна безпека України. Монография. Київ: 1999, 463с.

7. Ольшевськи В. Й. Воєнно-економічна безпека: теорія i практика. Наука $i$ оборона, №3, 1999.
8. Семененко, О. М., Бойко Р.В., Кремешний O.I. (2013) Методичний підхід щодо оцінювання рівня воєнно-економічної безпеки держави на основі оцінок рівнів забезпеченості ресурсами. Науковий журнал Системи озброєння і військова техніка. Харків, № 4 (36). С. $156-152$.

9. Семененко, О.М., Водчиць, О.Г. Бойко Р.В., Кострач В.В., Бердочник А.Д. (2016) Основні аспекти воєнно-економічної безпеки України та можливі шляхи ії забезпечення на середньо-строкову перспективу (2016-2020рр.).Науковий журнал Системи озброєння і військова техніка. Харків, № 3(47). С. 123 - 129.

10. Заде, Л. Понятие лингвистической переменной и ёё применение к принятию приближённых решений. Москва: Мир, 1976.

11. Фишберн, П. Теория полезности для принятия решений. Москва: Наука,1978.

12. Василевич, Л.Ф. Теория риска. Київ: КІІМ, КБШ, 2002. 


\title{
О вопросе формирования шкал оценивания уровня
}

\section{(состояния) \\ военно-экономической \\ безопасности}

\section{государства}

\author{
Игорь Москаленко * А \\ "Corresponding author: соискатель, e-mail: kidmos@bigmir.net, ORCID: 0000-0002-7822-6419 \\ А Национальный университет оборони Украины имени Ивана Черняховского, пр-кт Воздухофлотский, 28, г. Киев, 03049, Украина
}

\begin{abstract}
Аннотация
В любой стране объем оборонных расходов зависит от уровня военной и экономической безопасности государства. То есть, чтобы адекватно отреагировать на изменения состояния военно-экономической безопасности страны необходимо оценить ее уровень с учетом ресурсных возможностей государства во время оценивания, и только после этого принимать решение о доли увеличение или уменьшение оборонных расходов страны. Построение шкалы оценивания уровня военно-экономической безопасности, которая позволяет исследовать чувствительность полученной оценки уровня военноэкономической безопасности государства к изменению входных данных и повысить стабильность принятых решений, по этой оценке, является актуальной и необходимой задачей сегодняшнего дня. В статье шкалу оценивания уровня военно-экономической безопасности предлагается задавать на основе нечетко-множественной математической модели. Использование нечетко-множественной математической модели для построения шкалы оценивания уровня военно-экономической безопасности, позволит оперировать частичными нечеткими показателям оценок по составляющим показателей ресурсного обеспечения военно-экономической безопасности государства с целью исследования вопросов анализа чувствительности полученной оценки уровня военноэкономической безопасности государства к изменению входных данных и повышения стабильности принятых решений в соответствии с этой оценкой.
\end{abstract}

Ключевые слова: военная безопасность, экономическая безопасность, военноэкономическая безопасность, оборонные компоненты, нечетко-множественная математическая модель, интегральная функция, ресурсные возможности, шкала оценивания.

\section{On the issue of formation of scales of assessment of the level (state) of military and economic security of the state}

\author{
Ihor Moskalenko * A \\ *Corresponding author: researcher, e-mail: kidmos@bigmir.net, ORCID: 0000-0002-7822-6419 \\ A The National Defence University of Ukraine named after Ivan Cherniakhovskyi, 28, Povitroflotskyi Ave., Kyiv, 03049, Ukraine
}

\begin{abstract}
In any country, the amount of defense spending depends on the level of military and economic security of the state. That is, in order to adequately respond to changes in the state of military and economic security of the country, it is necessary to assess its level taking into account the resource capabilities of the state at the time of assessment, and only then decide on the share of increasing or decreasing defense spending. Building a scale for assessing the level of military and economic security, which allows to investigate the sensitivity of the assessment of the level of military and economic security to changes in input data and increase the stability of decisions on this assessment is an urgent and necessary task today. It is proposed in the article, the scale for assessing the level of military and economic security to be set on the basis of fuzzy-multiple mathematical model. The use of fuzzy-multiple
\end{abstract}


mathematical model to build a scale for assessing the level of military and economic security, will allow to operate partial fuzzy indicators on the components of resource indicators of military and economic security of the state to study the sensitivity of the assessment of the level of military and economic security input data and increase the stability of decisions made in accordance with this assessment.

Keywords: military security, economic security, military-economic security, defense components, fuzzy-multiple mathematical model, integrated function, resource capabilities, evaluation scale.

\section{References}

1. "Pro rishennya Rady natsional'noyi bezpeky i oborony Ukrayiny vid 2 veresnya 2015 roku "Pro novu redaktsiyu Voyennoyi doktryny Ukrayiny" [On the decision of the National Security and Defense Council of Ukraine of September 2, 2015 "On the new version of the Military Doctrine of Ukraine"]: Ukaz Prezydenta Ukrayiny №555/2015 URL: www.president.gov.ua/documents/555201519443.

2. "Priorytety rozvytku Zbroynykh Syl Ukrayiny z urakhuvannyam uchasti u hibrydniy viyni 20152016" [Priorities of development of the Armed Forces of Ukraine taking into account participation in the hybrid war 2015-2016] URL: http//www.president.gov.ua / documents.

3. "Obgruntuvannya perspektyvy ekonomichnoho rozvytku Ukrayiny u 2015-2016 rr." [Rationale for the prospects of economic development of Ukraine in 2015-2016]. - URL: http//econa.org.ua/index.php/econ

4. "Pro osnovy natsional'noyi bezpeky Ukrayiny" [On the foundations of national security of Ukraine]: Zakon Ukrayiny (Vidomosti Verkhovnoyi Rady Ukrayiny (VVR), 2003, № 39, p.351).

5. Semenenko, O.M. Metodyka otsinyuvannya stanu ekonomichnoyi skladovoyi voyennoyi bezpeky Ukrayiny [Methods for assessing the state of the economic component of military security of Ukraine] / Yu.A. Gusak, MP Naumenko // Coll. Science. etc. Central Research Institute of the Armed Forces of Ukraine. Kyiv, 2012. № 4 (62). P. 39 - 49.

6. Muntiyan V.I. Ekonomichna bezpeka Ukrayiny [Economic security of Ukraine]. Monograph. Kyiv: 1999, 463p.
7. Ol'shevs'ky V.Y. Voyenno-ekonomichna bezpeka: teoriya i praktyka [Military and economic security: theory and practice]. Nauka i oborona, №3,1999.

8. Semenenko, O. M. Metodychnyy pidkhid shchodo otsinyuvannya rivnya voyennoekonomichnoyi bezpeky derzhavy na osnovi otsinok rivniv zabezpechenosti resursamy [Methodical approach to assessing the level of military and economic security of the state on the basis of assessments of resource levels] / R.V. Boyko, O.I. Kremeshnyy // Systemy ozbroiennia i viiskova tekhnika: quarterly sciences journal. Kharkiv: KhNUPS, 2013. № 4 (36). P. $156-152$.

9. Semenenko, O.M. Osnovni aspekty voyennoekonomichnoyi bezpeky Ukrayiny ta mozhlyvi shlyakhy yiyi zabezpechennya na seredn'ostrokovu perspektyvu (2016-2020 rr.) [Basic aspects of military and economic security of Ukraine and possible ways to ensure it in the medium term (2016-2020)] / O.H. Vodchyts', R.V. Boyko, V.V. Kostrach, A.D. Berdochnyk // Systemy ozbroiennia i viiskova tekhnika: quarterly sciences journal. Kharkiv: KhNUPS, 2016. № 3(47). S. $123-129$.

10.Zade, L. Ponyatye lynhvystycheskoy peremennoy $\mathrm{y}$ prymenenye $\mathrm{k}$ prynyatyyu pryblyzhënnykh reshenyy [The concept of a linguistic variable and its application to making approximate decisions.] Moscow: Mir, 1976.

11. Fishburne, P. Teoryya poleznosty dlya prynyatyya reshenyy [Utility theory for decision making.] Moscow: Nauka, 1978.

12. Vasilevich, L.F. Teoryya ryska. [Risk theory.] Kyiv: KIIM, KBSh,2002. 